\title{
Mineralogy and Beneficiation of Lamujärvi Syenites
}

\author{
Xiaosheng Yang1, Jukka Laukkanen ${ }^{1}$, Akseli Torppa ${ }^{2}$, Neea Heino ${ }^{1}$ \\ ${ }^{1}$ Geological Survey of Finland, GTK Mintec, Outokumpu, Finland \\ ${ }^{2}$ Geological Survey of Finland, Kuopio, Finland \\ Email: jason.yang@gtk.fi, jukka.laukkanen@gtk.fi, akseli.torppa@gtk.fi,neea.heino@gtk.fi
}

Received 25 July 2016; accepted 23 August 2016; published 26 August 2016

Copyright (C) 2016 by authors and Scientific Research Publishing Inc.

This work is licensed under the Creative Commons Attribution International License (CC BY).

http://creativecommons.org/licenses/by/4.0/

(c) (i) Open Access

\begin{abstract}
The Lamujärvi syenites intrusions occur within Svecofennian (ca. 1.92 Ga) gneisses, ca. 70 km west of the Otanmaki alkaline area in central Finland. Previous studies have revealed zones in the syenites that display strong enrichment in $\mathrm{Zr}$ (1587 ppm), Nb (up to 685 ppm), Ta (up to 82 ppm), and REE (up to $5350 \mathrm{ppm}$ ). The major REE-bearing minerals in the Lamujarvi syenites are allanite and monazite. A sample of the Lamujärvi syenites with the REE content of 4700 ppm was studied on the mineralogy and beneficiation at GTK Mintec. The mineralogical analysis was conducted by MLA. The REE-bearing minerals allanite, parisite, zircon, and apatite were identified at significant concentrations and high contents of titanite $(15.4 \%)$, biotite $(30.9 \%)$ and magnetite $(8.2 \%)$ were displayed in the sample. The beneficiation experiments by flotation, wet low and high gradient magnetic separations and gravity separation with a shaking table were carried out. A composite REE-Ti concentrate with REE 23,000 ppm, Zr 5000 ppm, Nb 3400 ppm and Ti0 $25.5 \%$ at REE and Ti recoveries of $57 \%$ and $54 \%$ was obtained. In addition, biotite and magnetite concentrates were gained as by-products.
\end{abstract}

\section{Keywords}

The Lamujärvi Syenites, Mineralogy, Beneficiation, Allanite, Titanite

\section{Introduction}

No REE are currently mined in Europe, but potential resources are known to be widespread, and many are being explored [1]. Finland has high potential for exploration of REE and the known examples of REE mineralisation occur in carbonatitic and alkaline intrusives, granites, hydrothermal rocks and kaolinitic saprolites (Figure 1). There are currently no economic REE deposits in Finland, although REE were extracted between 1963 and 1972 from apatite concentrate mined as a by-product in the Korsnäs lead (Pb)-REE mine in western Finland [2]. REE could potentially be extracted in the future as a by-product of mining for commodities such as phosphorus (P) 
and gold (Au).

As shown in Figure 1, Finland is situated in the central part of the Fennoscandian shield, which is the largest outcropping Precambrian domain in Europe. The shield hosts a few sub-economic to economic REE deposits mostly with the intrusions of the Devonian Kola alkaline province in Russia [3] [4]. The Sokli carbonatite complex (total area $20 \mathrm{~km}^{2}$ ) and the Iivaara ijolite complex in Finland are the westernmost intrusions of the Devonian Kola alkaline province. Other potentially economic REE deposits in Fennoscandia include the Norra Kärr in Sweden. Currently, the most promising REE deposit is associated with the Sokli carbonatite complex in north eastern Finland. The Sokli carbonatite (approximately 360 - $380 \mathrm{Ma}$ ) hosts an unexploited deeply weathered phosphate deposit enriched in niobium (Nb), tantalum (Ta), zirconium (Zr), REE and uranium (U). The carbonatite intrusion consists of a magmatic phoscorite-carbonatite core, surrounded by metacarbonatite and a wide fenite aureole, altogether about $9 \mathrm{~km}$ in diameter. Late-stage carbonatite veins in the magmatic core and in the fenite zone have high potential for REE mineralisation [5] [6].

The Lamujärvi plutons are located ca. $70 \mathrm{~km}$ west of the Otanmäki area, which hosts Nb-REE mineralisations in alkaline gneisses, but despite the spatial proximity, in light of the $200 \mathrm{Ma}$ age difference suggested by recent $\mathrm{U}-\mathrm{Pb}$ (zircon) dating of the Lamujärvi syenite at ca. $1.85 \mathrm{Ga}$ and the Otanmäki granite at ca. $2.05 \mathrm{Ma}$, a genetic relationship between the two occurrences is improbable. The Lamujärvi syenites in central Finland display strong enrichment in $\mathrm{Zr}$ (1587 ppm), Nb (up to $685 \mathrm{ppm}$ ), Ta (up to $82 \mathrm{ppm}$ ) and REE (up to $5350 \mathrm{ppm}$ ). The major REE-bearing minerals in the enriched rocks are allanite and monazite [7]. Meanwhile, other valuable minerals such as titanite, biotite and magnetite are at high concentrations which could be economically recovered. In this paper, the mineralogy and the beneficiation of the Lamujärvi syenites are studied.

\section{Experimental and Reagents}

A sample of the Lamujarvi syenites over $100 \mathrm{~kg}$ collected from Lamujärvi area was received at GTK Mintec in 2012. The sample was crushed by a jaw and a roll crusher to $-1.5 \mathrm{~mm}$ and split into $1.5 \mathrm{~kg}$ amount of subsamples which were stored for beneficiation experiments. One of the subsamples was further split into $100 \mathrm{~g}$ amount of samples for chemical and mineralogical analyses.

Chemical analyses of the sample were conducted by XRF, ICP-OES and ICP-MS at Labtium Oy in Finland. A Mineral Liberation Analyzer (MLA) was used for mineralogical analysis at GTK Mintec which consists of the standard modern SEM (FEI Quanta 600) with the energy dispersive X-ray analyzer (EDAX Genesis with two detectors) and the software package developed originally by JKTech (Australia) [8] [9]. The modal mineralogy of the samples was analyzed by the XMOD-STD and XBSE-STD methods, which were point counting methods, and the grain size was analyzed by the XBSE method.

The samples of $1.5 \mathrm{~kg}$ with the size of $-1.5 \mathrm{~mm}$ were ground at a laboratory rod mill as the head samples for beneficiation experiments. Flotation experiments were carried out using an Outotec laboratory flotation machine. Flotation cells with the volumes of 4 and 1.5 liters were used in rougher and cleaner flotation, respectively. Tap water was used for wet grinding and flotation. The room temperature $\left(20^{\circ} \mathrm{C}-23^{\circ} \mathrm{C}\right)$ was applied for flotation conditioning. A laboratory shaking table was used for gravity concentration at the conditions of inclination $3^{\circ}-$ $4^{\circ}$, feed rate $0.3 \mathrm{~kg} / \mathrm{h}$, stroke $350 / \mathrm{min}$, slurry density $25 \%$ and rate of rinse water $6 \mathrm{l} / \mathrm{min}$. Wet low intensity magnetic separation (WLIMS) experiments were performed by using a Sala laboratory roller type magnetic separator with the magnetic field of 0.07 Tesla. A laboratory high gradient magnetic separator (Sala HGMS 10-1520 SCR) was used for the high gradient magnetic separation (HGMS) experiments. The matrix type of 3.5 XRO with the aperture size of $750 \mu \mathrm{m}$ was used. The magnetic intensities of 1.5 and 2 Tesla were applied for roughing process and 0.2 Tesla for cleaning process.

To avoid negative effects of slimes on beneficiation desliming was conducted by a hydraulic sedimentation method to remove the fine fraction of $-20 \mu \mathrm{m}$ after material grinding. Acid leaching testwork by using hydrochloric acid $(\mathrm{HCl})$ was performed for the treatment of slimes. The $37 \% \mathrm{HCl}$ was used and diluted into required concentration for leaching. The volume of the leaching tank was $1000 \mathrm{ml}$, the ratio of solid to acid solution $75 \mathrm{~g} / 500 \mathrm{ml}$ and the agitation speed $180 \mathrm{rpm}$. The acid concentration was $6 \mathrm{~mol} / \mathrm{l}$ and leaching temperature $60^{\circ} \mathrm{C}$ which was controlled by circulation of heated water. The leaching times tested were $60 \mathrm{~min}, 120 \mathrm{~min}$ and 180 min. After leaching the residues were filtered, dried, weighted and assayed by XRF.

In biotite flotation, two cationic collectors tallow amine and Aero 3030C supplied by Cytec were used and in REE-Ti flotation hydroxamate type of reagent Aero6494 and sulfosuccinamate type of reagent Aero 845 from Cytec, FS-2 an anonic collector, and petroleum sulfonate were applied. 


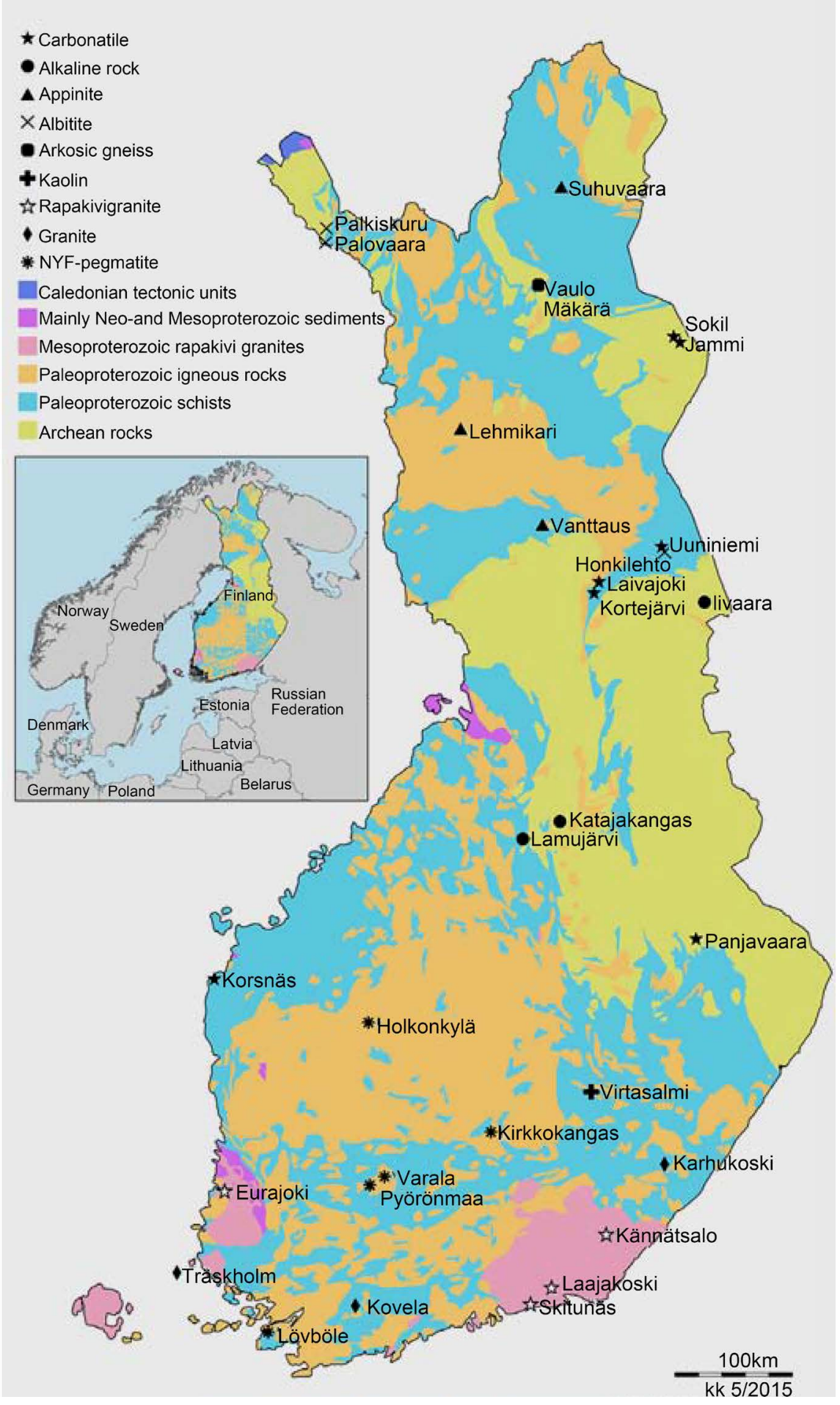

Figure 1. Simplified geological map of Finland showing the distribution of REE occurrences (the occurrences are classified by rock types) [7].

\section{Results and Discussion}

\subsection{Chemical Compositions}

The REE contents determined by ICP-OES and ICP-MS are shown in Table 1. Total sixteen rare earth elements 
were found but seven of them including La, Ce, Pr, Nd, Sm, Gd and Y with significant contents over $100 \mathrm{ppm}$. The REE with the highest content is Ce that is $2060 \mathrm{ppm}$. The total REE (TREE) is $4729 \mathrm{ppm}$ or $0.47 \%$ and the ratio of the light (LREE) and heavy REE (HREE) is 91\%/9\%. The contents of the major elements determined by $\mathrm{XRF}$ are shown in Table 2. The elements $\mathrm{Nb}$ and $\mathrm{Zr}$ were found to be with significant contents, i.e., $\mathrm{ZrO} 0.18 \%$ or $1800 \mathrm{ppm}, \mathrm{Nb} 0.066 \%$ or $660 \mathrm{ppm}$. The contents of Th and $\mathrm{U}$ are ignorable. The relatively high concentrations of $\mathrm{TiO}_{2}, \mathrm{FeO}$ and $\mathrm{MgO}$ in the sample are explained by abundant titanite, biotite and magnetite which could be recovered as co-product and by-products.

\subsection{Mineralogical Studies}

Modal mineralogy of the sample with the chemical formulas and physical properties of the contained minerals are shown in Table 3. A total of 18 minerals were identified by MLA (over 52000 points were measured) in which $89.5 \%$ are silicates, and other remained are Fe-oxides $8.6 \%$, phosphates $1.24 \%$ and carbonates $0.48 \%$. The main silicate minerals are biotite $31.6 \%$, plagioclase $30.9 \%$, titanite $15.4 \%$, garnet $2.4 \%$ and allanite $1.9 \%$. The Fe-oxides are magnetite $8.2 \%$, goethite $0.3 \%$ and ilmenite $0.1 \%$. The phosphate is apatite $1.24 \%$ and the carbonate calcite $0.48 \%$. The identified REE minerals are allanite and parisite. Most the REE are contained in allanite because of very low concentration of parisite. Meanwhile, REE may be also contained in apatite and zircon in trace contents.

The SEM images of REE minerals allanite, parisite and zircon are shown in Figure 2. The allanite particles are clearly found in liberated and coarse grain sizes. The particles of zircon also appear in smaller grain sizes and some are liberated. But the parisite particles are found in very fine grain size and tightly locked in other minerals like silicates, titanite, calcite and allanite etc. The grain sizes of REE minerals allanite, parisite and zircon are presented in Figure 3. Allanite has a coarse grain size, i.e., P80 $=400 \mu \mathrm{m}$, however, zircon and parisite are much finely grained, i.e., $\mathrm{P} 80=70 \mu \mathrm{m}$ for zircon and P80 $=50 \mu \mathrm{m}$ for parisite.

\subsection{Beneficiation Studies}

\subsubsection{Design of Flowsheet}

As shown in Table 3, the sample contains high contents of magnetite and biotite. Magnetite is a ferromagnetic

Table 1. The REE contents in the sample.

\begin{tabular}{|c|c|c|c|c|c|c|c|c|}
\hline $\begin{array}{c}\mathrm{La} \\
\mathrm{ppm}\end{array}$ & $\begin{array}{c}\mathrm{Ce} \\
\mathrm{ppm}\end{array}$ & $\begin{array}{c}\mathrm{Pr} \\
\mathrm{ppm}\end{array}$ & $\begin{array}{c}\mathrm{Nd} \\
\mathrm{ppm}\end{array}$ & $\begin{array}{c}\mathrm{Sm} \\
\mathrm{ppm}\end{array}$ & $\begin{array}{c}\mathrm{Eu} \\
\mathrm{ppm}\end{array}$ & $\begin{array}{c}\mathrm{Gd} \\
\mathrm{ppm}\end{array}$ & $\begin{array}{c}\mathrm{Tb} \\
\mathrm{ppm}\end{array}$ & $\begin{array}{c}\text { Dy } \\
\text { ppm }\end{array}$ \\
\hline 859 & 2060 & 261 & 990 & 140 & 7 & 110 & 12 & 52 \\
\hline \multirow{2}{*}{$\begin{array}{c}\text { Ho } \\
\text { ppm }\end{array}$} & \multirow{2}{*}{$\begin{array}{c}\mathrm{Er} \\
\mathrm{ppm}\end{array}$} & \multirow{2}{*}{$\begin{array}{c}\text { Tm } \\
\mathrm{ppm}\end{array}$} & \multirow{2}{*}{$\begin{array}{c}\mathrm{Yb} \\
\mathrm{ppm}\end{array}$} & \multirow{2}{*}{$\begin{array}{c}\mathrm{Lu} \\
\mathrm{ppm}\end{array}$} & \multirow{2}{*}{$\begin{array}{c}\mathrm{Y} \\
\mathrm{ppm}\end{array}$} & \multicolumn{2}{|c|}{ TREE } & \multirow{2}{*}{$\mathrm{LR} / \mathrm{HR}^{\mathrm{a}}$} \\
\hline & & & & & & ppm & wt \% & \\
\hline 8 & 22 & 2 & 12 & 2 & 193 & 4729 & 0.47 & $91 \% / 9 \%$ \\
\hline
\end{tabular}

${ }^{\mathrm{a}}$ Light REE to heavy REE ratio.

Table 2. The major element contents in the sample (wt\%).

\begin{tabular}{|c|c|c|c|c|c|c|}
\hline $\mathrm{SiO}_{2}$ & $\mathrm{TiO}_{2}$ & $\mathrm{Al}_{2} \mathrm{O}_{3}$ & $\mathrm{FeO}$ & $\mathrm{CaO}$ & $\mathrm{MgO}$ & $\mathrm{Na}_{2} \mathrm{O}$ \\
\hline 44.8 & 5.35 & 14.2 & 14.6 & 5.91 & 3.18 & 3.92 \\
\hline $\mathrm{K}_{2} \mathrm{O}$ & $\mathrm{ZrO}$ & $\mathrm{P}_{2} \mathrm{O}_{5}$ & $\mathrm{Nb}$ & Th & $\mathrm{U}$ & C \\
\hline 4.06 & 0.18 & 0.56 & 0.066 & 0.004 & 0.00 & 0.119 \\
\hline
\end{tabular}


Table 3. Modal mineralogy of the sample.

\begin{tabular}{|c|c|c|c|c|}
\hline Mineral & Formula & Wt\% & S.G & Magnetic property \\
\hline Quartz & $\mathrm{SiO}_{2}$ & 0.84 & $2.59-2.63$ & \\
\hline Plagioclase & $\mathrm{NaAlSi}_{3} \mathrm{O}_{8}-\mathrm{CaAl}_{2} \mathrm{Si}_{2} \mathrm{O}_{8}$ & 30.87 & $2.62-2.76$ & Diamagnetic \\
\hline K_feldspar & $\mathrm{KAlSi}_{3} \mathrm{O}_{8}$ & 6.04 & $2.55-2.76$ & Diamagnetic \\
\hline Biotite & $\mathrm{K}(\mathrm{Mg}, \mathrm{Fe})_{3}\left(\mathrm{AlSi}_{3} \mathrm{O}_{10}\right)(\mathrm{F}, \mathrm{OH})_{2}$ & 31.63 & $2.7-3.3$ & Paramagnetic \\
\hline Chlorite & $\mathrm{NaClO}_{2}$ & 0.03 & & Diamagnetic \\
\hline Fe_tschermakite & $\mathrm{Ca}_{2} \mathrm{Fe}_{3}^{2+} \mathrm{AlFe}^{3+}\left(\mathrm{Si}_{6} \mathrm{Al}_{2} \mathrm{O}_{22}\right)(\mathrm{OH})_{2}$ & 0.09 & 3.41 & \\
\hline Garnet & $\left(\mathrm{SiO}_{4}\right)_{3}$ & 2.41 & $3.1-4.3$ & \\
\hline Titanite & $\mathrm{CaTiSiO}_{5}$ & 15.43 & 3.48 to 3.60 & Paramagnetic \\
\hline Calcite & $\mathrm{CaCO}_{3}$ & 0.48 & 2.71 & \\
\hline Apatite & $\mathrm{Ca}_{5}\left(\mathrm{PO}_{4}\right)_{3}(\mathrm{~F}, \mathrm{Cl}, \mathrm{OH})$ & 1.24 & $3.16-3.22$ & Diamagnetic \\
\hline Zircon & $\mathrm{ZrSiO}_{4}$ & 0.37 & $4.6-4.7$ & Diamagnetic \\
\hline Allanite & $(\mathrm{Ce}, \mathrm{Ca}, \mathrm{Y}, \mathrm{La})_{2}\left(\mathrm{Al}, \mathrm{Fe}^{+3}\right)_{3}$ & 1.87 & $3.5-4.2$ & Paramagnetic \\
\hline Parisite & $\underline{\mathrm{Ca}}(\underline{\mathrm{Ce}}, \underline{\mathrm{La}})_{2}\left(\underline{\mathrm{CO}}_{3}\right)_{3} \underline{\mathrm{F}}_{2}$ & 0.01 & 4.34 & \\
\hline Goethite & $\mathrm{FeO}(\mathrm{OH})$ & 0.29 & $3.3-4.3$ & \\
\hline Magnetite & $\mathrm{Fe}_{3} \mathrm{O}_{4}$ & 8.21 & $5.17-5.18$ & Ferromagnetic \\
\hline Ilmenite & $\mathrm{FeTiO}_{3}$ & 0.12 & $4.70-4.79$ & Paramagnetic \\
\hline Pseudorutile & $\mathrm{Fe}_{2} \mathrm{Ti}_{3} \mathrm{O}_{9}$ & 0.01 & & \\
\hline Unclassified & & 0.05 & & \\
\hline Total & & 100.00 & & \\
\hline
\end{tabular}

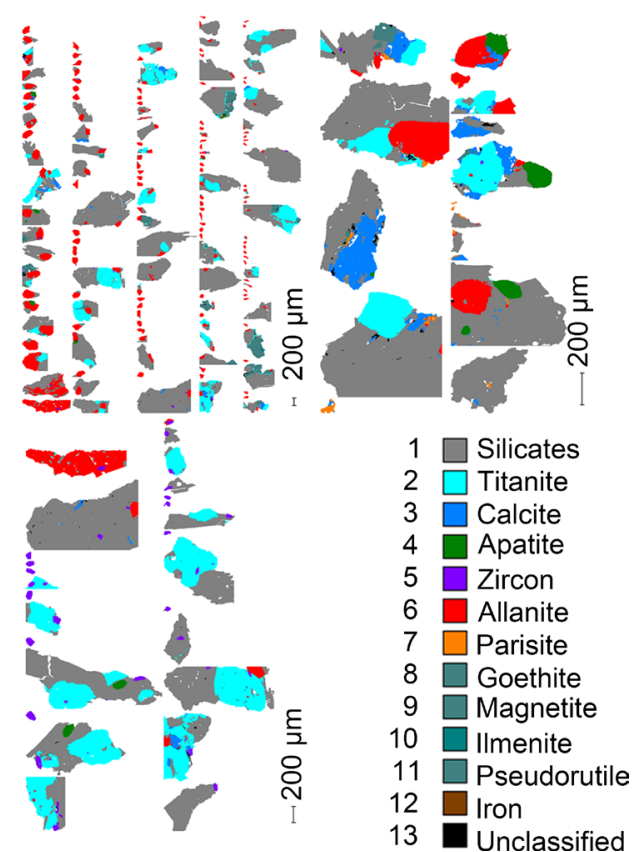

Figure 2. SEM images of REE minerals, allanite, parisite and zircon. 


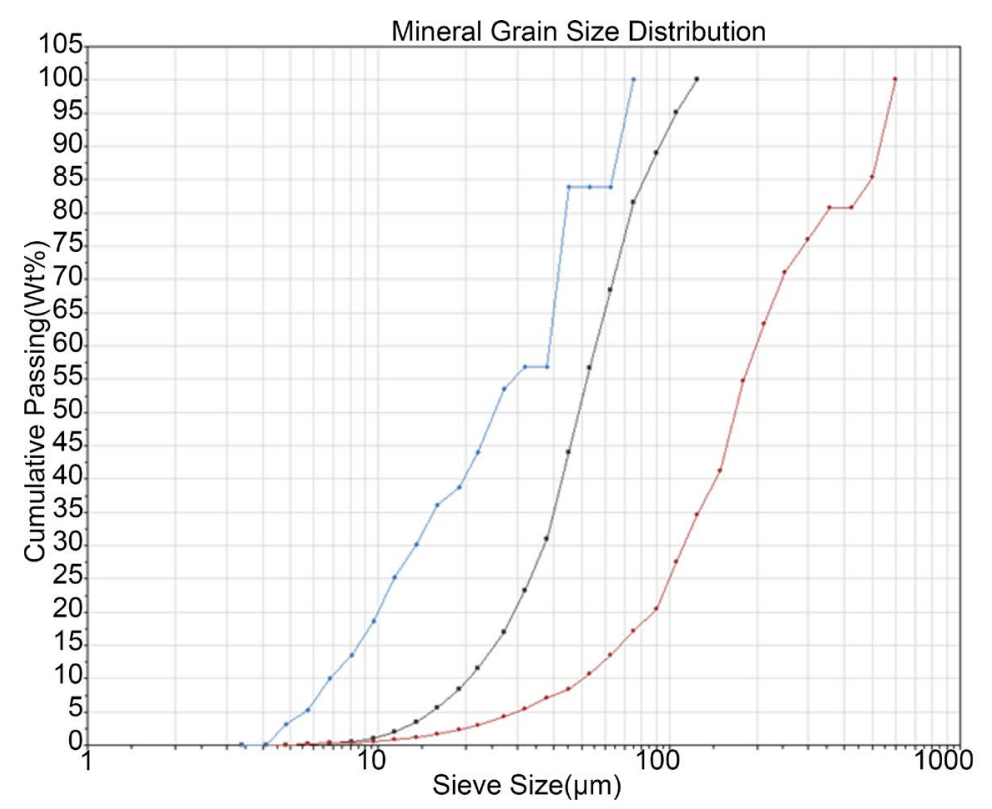

:Feed-1.5 mm-Ungrouped-Zircon-Equivalent Circle-4 Sqrt 2
:Feed-1.5 mm-Ungrouped-Allanite-Equivalent Circle-4 Sqrt 2
- Feed-1.5 mm-Ungrouped-Parisite-Equivalent Circle-4 Sqrt 2

Figure 3.The grain sizes of REE minerals allanite, parisite and zircon.

mineral and easily separated by low intensity magnetic separation. With a good floatability by using amine collector biotite can be recovered by flotation effectively. As the most important REE mineral in the sample allanite is a paramagnetic mineral and also a heavier mineral comparing to other major gangue minerals in the sample (plagioclase, K_feldspar and quartz) and could be concentrated by gravity and high gradient or intensity magnetic separations, and flotation. Meanwhile, titanite is also a paramagnetic and heavier mineral and could be recovered with allanite as co-product.

Rough experiments of gravity separation, high gradient magnetic separation and flotation were performed and a combination flowsheet was determined as illustrated in Figure 4. After grinding the slimes of $-20 \mu \mathrm{m}$ is removed by desliming. Then magnetite is recovered by WLIMS followed by biotite flotation. Finally, allanite and titanite are concentrated by gravity concentration with shaking tabling, flotation and HGMS as bulk REE-Ti concentrates.

\subsubsection{Parametric Experiments and Results}

The amount of the feed sample for each experiment was $3 \mathrm{~kg}$ and the grinding size was P80 $=85 \mu \mathrm{m}$ which was determined based on overall analysis of mineral associations and liberations. Through roughing and cleaning process of WLIMS the magnetite concentrate with the grade of $\mathrm{FeO} 87 \%$ was obtained with low losses of REE and $\mathrm{TiO}_{2}(<1.0 \%)$. The WLIMS tailings (rougher and cleaner tailings combination) was reported to the biotite flotation in which the slurry was conditioned for $5 \mathrm{~min}$ at a high density $(>60 \%)$ with addition of amine collector and kerosene at $\mathrm{pH} 3.0$ by using $\mathrm{H}_{2} \mathrm{SO}_{4}$ and then the biotite flotation was performed at $\mathrm{pH}$ 3.0. Two kinds of amine collectors tallow amine and Aero3030C were tested with kerosene as the assistant collector. The biotite flotation results indicated by $\mathrm{MgO}$ grade and recovery using the two collectors are shown in Figure 5. It is demonstrated that higher recovery of MgO (biotite) was obtained by using Aero 3030C. The losses of REE (indicated by $\mathrm{Ce}$ ) and $\mathrm{TiO}_{2}$ during the biotite flotation for both collectors are compared in Figure 6. Generally, the loss of REE in the biotite concentrate was quite low $(<20 \%)$ for both collectors but slightly lower recovery of REE was obtained while using tallow amine. Comparing to Aero 3030C, the loss of $\mathrm{TiO}_{2}$ in the biotite concentrate was significantly lower while using tallow amine.

After the biotite flotation gravity concentration by shaking tabling, flotation and HGMS were performed for recovery of REE-bearing minerals (mainly allanite) and titanite. The operation conditions of shaking tabling were inclination $3^{\circ}-4^{\circ}$, feed rate $0.3 \mathrm{~kg} / \mathrm{h}$, stroke $350 / \mathrm{min}$, slurry density $25 \%$ and rate of rinse water $6 \mathrm{l} / \mathrm{min}$ 


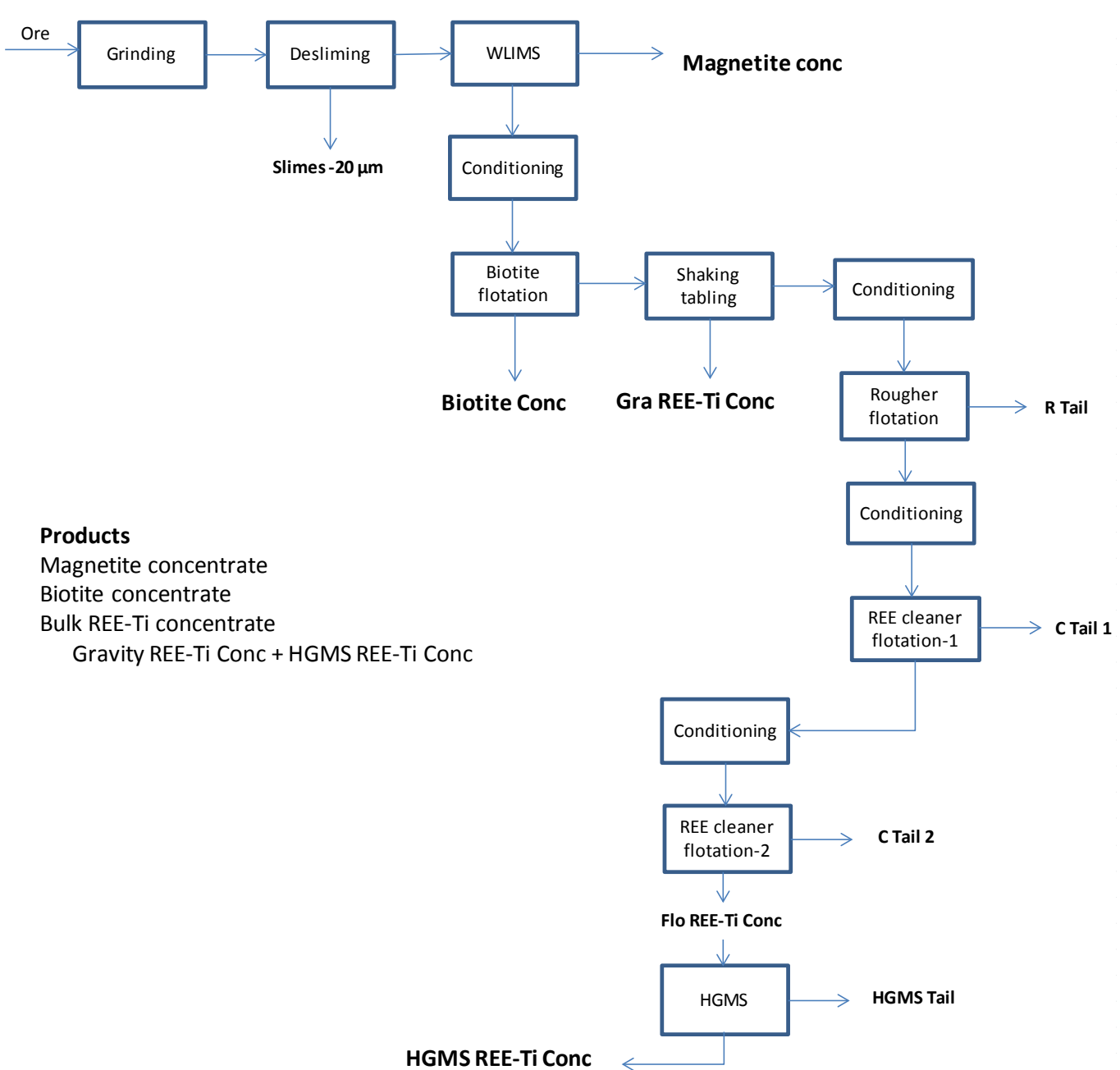

Figure 4. Beneficiation flowsheet of the Lamujärvi syenites.

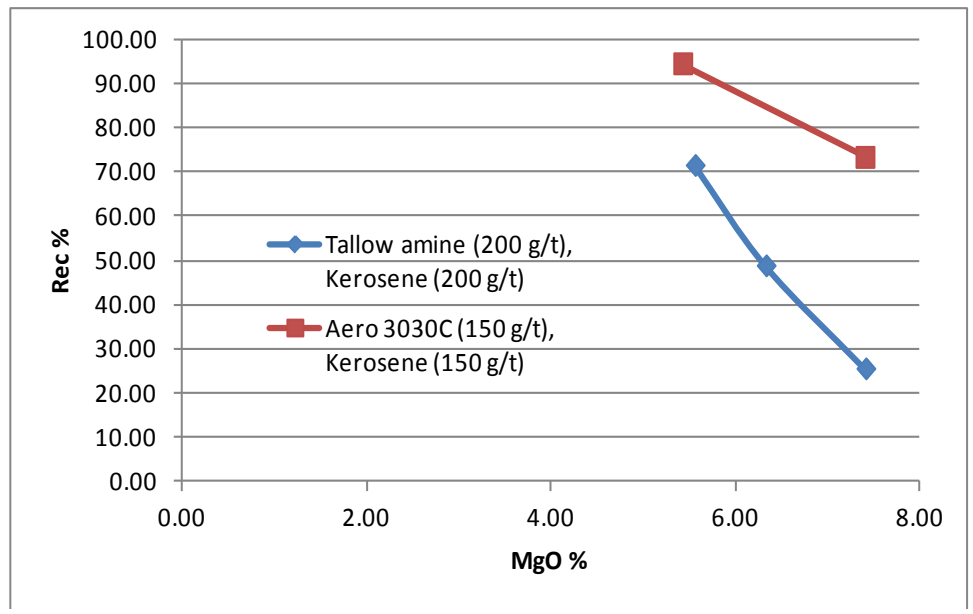

Figure 5. MaO grade and recovery of biotite flotation concentrate.

which were determined by observing the stratification and distribution status of the material on the table. During the tabling most coarse particles of allanite and titanite were concentrated as the Gra REE-Ti concentrate and the tailings from the shaking table mainly containing fine allanite and titanite particles was reported to the REE-Ti 
flotation circuit where the slurry was conditioned for 5 min with additions of chemicals at high density (>60\%) prior to flotation. The $\mathrm{pH}$ values were adjusted to the optimal depending on collectors which were in the range of pH 6 to 9. In the roughing stage three collectors Aero 6494, FS-2 and P Sulfonate (petroleum sulfonate) combined with Aero 845 were tested. Experimental results of the rougher flotation with different collectors displayed by the relationships between $\mathrm{Ce}$ and $\mathrm{TiO}_{2}$ recoveries and the weight recoveries (yields) of concentrate are shown in Figure 7. Comparing to Aero 6494 and FS-2, the combination of P Sulfonate and Aero 845 as the collector shows significantly more selective for flotation of REE (Ce) with higher Ce recoveries at the same yields. For flotation of $\mathrm{TiO}_{2}$ both collector FS-2 and the combination of P Sulfonate and Aero 845 have a very good selectivity although FS-2 performs slightly more efficient for $\mathrm{TiO}_{2}$ flotation.

Being more selective for flotation of REE the combination of P Sulfonate and Aero 845 was selected as the collector for the cleaner flotation and the experimental results are shown in Figure 8. It is seen that the curves of Ce and $\mathrm{TiO}_{2}$ grade-recovery display high efficiencies of both $\mathrm{REE}$ and $\mathrm{TiO}_{2}$ flotation.

The suitable magnetic intensities of the high gradient separation were defined by roughly testing, that is, 1.5 and 2 Tesla were applied for roughing process and 0.2 Tesla for cleaning process.

\subsubsection{Overall Beneficiation Results}

The overall beneficiation results of the Lamujärvi syenites are presented in Table 4 and Table 5. The REE-Ti concentrate which is the composite of gravity and HGMS REE-Ti concentrates has the grade of REE (La, Ce, Y) $15,235 \mathrm{ppm}$ (TREE around 23,000 ppm) at the recovery of $57.2 \%$ and the grade of $\mathrm{TiO}_{2} 25.5 \%$ at the recovery of $54.0 \%$. In addition, as the by-products, the magnetic concentrate with the grade of $\mathrm{FeO} 86.6 \%$ at the recovery of $45.6 \%$ and the biotite concentrate with the grade of $\mathrm{MgO} 6.6 \%$ at the recovery of $51.0 \%$ were obtained.

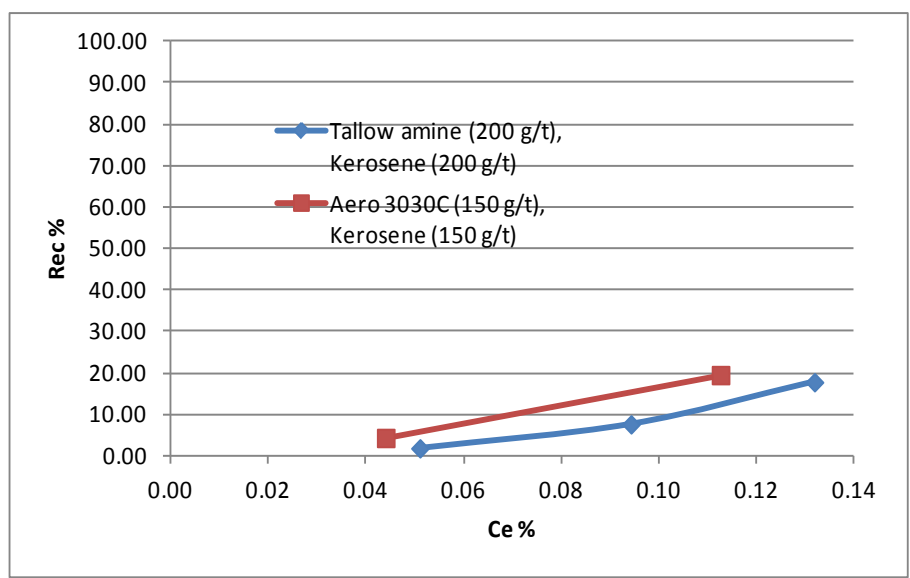

(a)

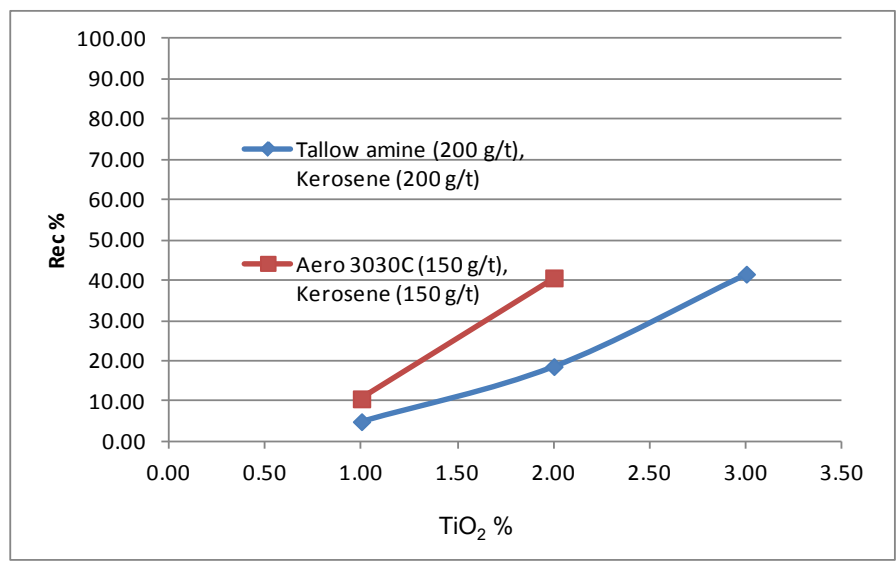

(b)

Figure 6. Recoveries and grades of $\mathrm{Ce}$ and $\mathrm{TiO}_{2}$ in biotite concentrate. 


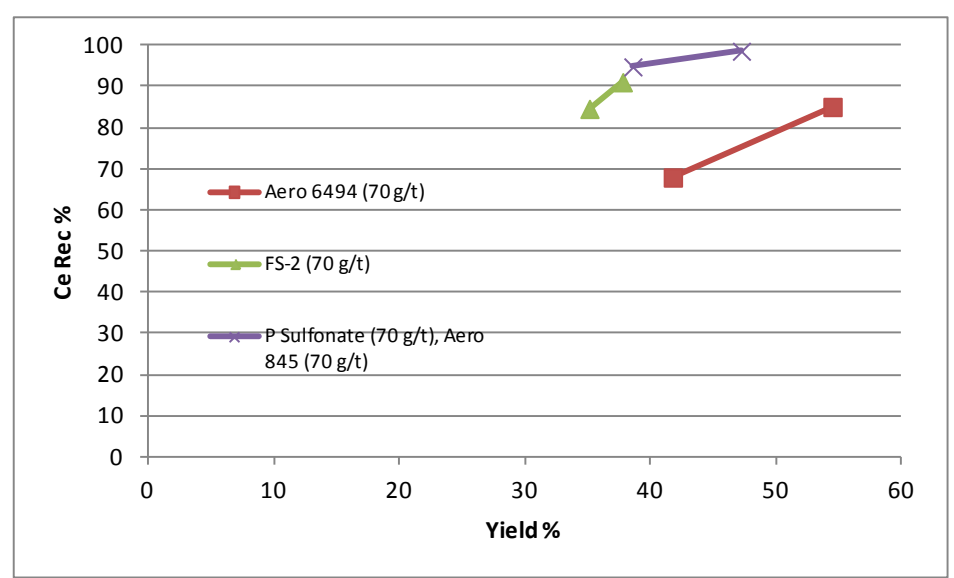

(a)

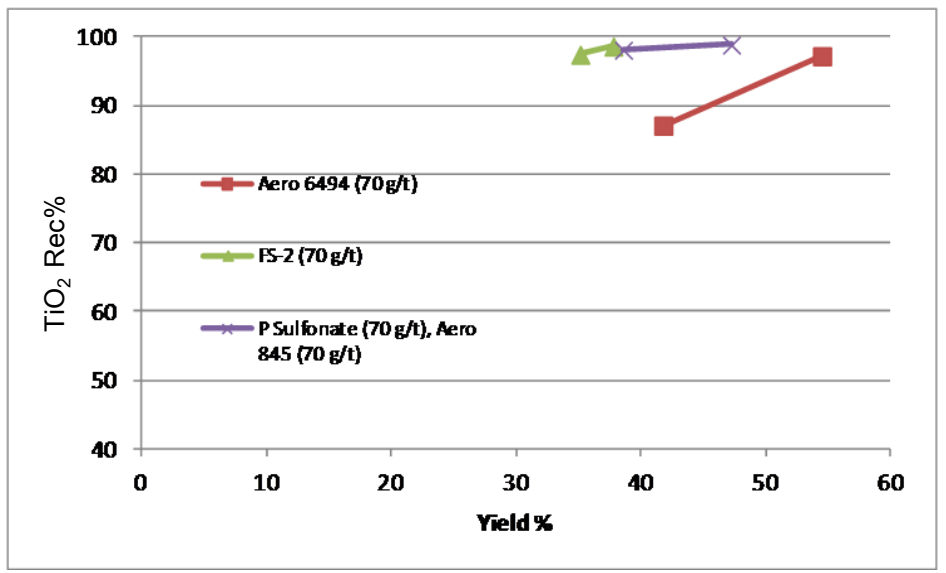

(b)

Figure 7. Experimental results of the rougher flotation with different collectors.

For analyzing the experimental errors the element contents of the feed by calculation from the experimental results (Calc'd Feed $\left(X_{1}\right)$ ) and by the analysis (Analysis Feed $\left(X_{2}\right)$ ) are listed in Table 4 and Table 5 . The standard deviation (SD) between the calculated feed $\left(X_{1}\right)$ and the analysis feed $\left(X_{2}\right)$ was determined by following Equation.

$$
S D=\sqrt{\frac{1}{2-1} \sum\left(X_{i}-X_{m}\right)^{2}}
$$

where $X_{\mathrm{i}}$ is the content of element $i$ and $X_{\mathrm{m}}$ is the mean value of $X_{1}$ and $X_{2}$.

The values of SD for all the elements listed in Table 4 and Table 5 present that the experimental errors are very small.

\subsubsection{Treatment of Slimes by HCl Leaching}

It is noticed in Table 4 and Table 5 that 23.4\% of REE and 20.8\% of $\mathrm{TiO}_{2}$ were deposited in the slimes fraction which is hardly enriched by physical methods (flotation, gravity and magnetic separations) due to very fine particles. Acid leaching testwork using hydrochloric acid $(\mathrm{HCl})$ was performed to assess the leachabilty of REE for the slimes. The extraction rates of elements in the solution are shown in Table 6. It is revealed that the recoveries of La and Ce in the solution are high. The $89.3 \% \mathrm{La}$ and $79.8 \%$ Ce were obtained at the leaching time 180 min. The extraction of $\mathrm{P}_{2} \mathrm{O}_{5}$ was over $91 \%$. That is, allanite as the major REE-containing mineral in the slimes and also apatite were mostly decomposed. Meanwhile, the extraction of $\mathrm{TiO}_{2}$ was low $(<18.0 \%)$ and $\mathrm{SiO}_{2}$ as am impurity was remained in the solid in almost $100 \%$. 


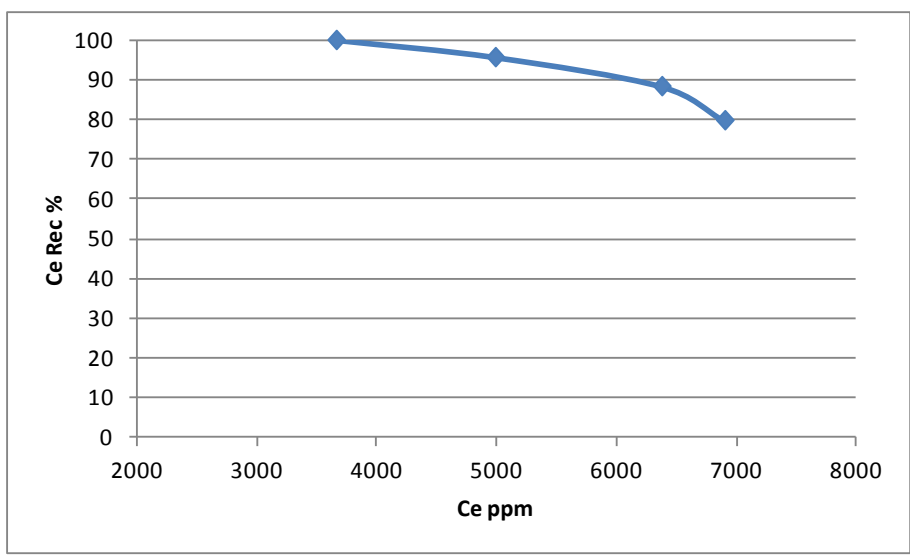

(a)

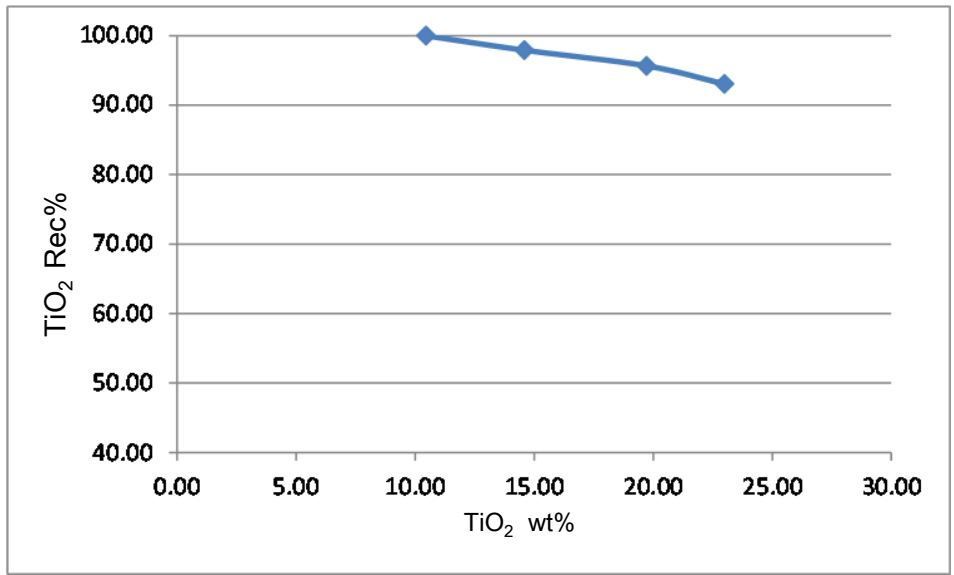

(b)

Figure 8. Experimental results of the cleaner flotation (P sulfonate $25 \mathrm{~g} / \mathrm{t}$ and Aero $84550 \mathrm{~g} / \mathrm{t}$; conditioning for $5 \mathrm{~min}$; $\mathrm{pH}$ 6).

Table 4. Beneficiation results of the Lamujärvi syenites (assayed by XRF).

\begin{tabular}{|c|c|c|c|c|c|c|c|c|c|}
\hline \multirow{2}{*}{ Product } & \multirow{2}{*}{$\begin{array}{c}\text { Yield } \\
\%\end{array}$} & \multicolumn{2}{|c|}{ La } & \multicolumn{2}{|c|}{$\mathrm{Ce}$} & \multicolumn{2}{|c|}{$\mathbf{Y}$} & \multicolumn{2}{|c|}{ REE (La, Ce, Y) } \\
\hline & & ppm & Rec \% & ppm & Rec \% & ppm & Rec \% & ppm & $\operatorname{Rec} \%$ \\
\hline Slimes $(-20 \mu \mathrm{m})$ & 29.1 & 800 & 24.9 & 1690 & 23.0 & 120 & 18.1 & 2610 & 23.4 \\
\hline Magnetite Conc & 8.3 & 120 & 1.1 & 180 & 0.7 & 11 & 0.5 & 311 & 0.8 \\
\hline Biotite Conc & 23.4 & 270 & 6.8 & 742 & 8.1 & 127 & 15.4 & 1140 & 8.6 \\
\hline REE-Ti Conc & 12.4 & 4215 & 55.4 & 10,089 & 57.8 & 931 & 58.7 & 15,235 & 57.2 \\
\hline Tail & 26.8 & 416 & 11.8 & 839 & 10.4 & 54 & 7.3 & 1310 & 10.7 \\
\hline Calc'd Feed $\left(\mathrm{X}_{1}\right)$ & 100.0 & 940 & 100.0 & 2157 & 100.0 & 196 & 100.0 & 3293 & 100.0 \\
\hline \multicolumn{2}{|c|}{ Analysis Feed $\left(\mathrm{X}_{2}\right)$} & \multicolumn{2}{|l|}{859} & \multicolumn{2}{|l|}{2060} & \multicolumn{2}{|l|}{193} & \multicolumn{2}{|l|}{3113} \\
\hline \multicolumn{2}{|c|}{ Standard deviation (SD) } & \multicolumn{2}{|l|}{57.3} & \multicolumn{2}{|l|}{68.4} & \multicolumn{2}{|l|}{1.6} & \multicolumn{2}{|l|}{127.3} \\
\hline
\end{tabular}


Table 5. Beneficiation results of the Lamujärvi syenites (assayed by XRF).

\begin{tabular}{|c|c|c|c|c|c|c|c|c|c|}
\hline \multirow{2}{*}{ Product } & \multirow{2}{*}{$\begin{array}{c}\text { Yield } \\
\%\end{array}$} & \multicolumn{2}{|c|}{ FeO } & \multicolumn{2}{|c|}{$\mathrm{SiO}_{2}$} & \multicolumn{2}{|c|}{ MgO } & \multicolumn{2}{|c|}{$\mathrm{TiO}_{2}$} \\
\hline & & $\%$ & $\operatorname{Rec} \%$ & $\%$ & $\operatorname{Rec} \%$ & $\%$ & $\operatorname{Rec} \%$ & $\%$ & Rec \% \\
\hline $\begin{array}{l}\text { Slimes } \\
(-20 \mu \mathrm{m})\end{array}$ & 29.1 & 12.0 & 22.2 & 47.7 & 31.4 & 4.5 & 43.6 & 4.1 & 20.8 \\
\hline Magnetite Conc & 8.3 & 86.6 & 45.6 & 1.89 & 0.4 & 0.1 & 0.2 & 0.5 & 0.7 \\
\hline Biotite Conc & 23.4 & 17.6 & 26.1 & 39.9 & 21.1 & 6.6 & 51.0 & 4.3 & 17.3 \\
\hline REE-Ti Conc & 12.4 & 4.8 & 3.8 & 31.6 & 9.2 & 0.2 & 1.0 & 25.5 & 54.0 \\
\hline Tail & 26.8 & 1.4 & 2.4 & 62.8 & 37.9 & 0.5 & 4.1 & 1.6 & 7.1 \\
\hline Calc'd Feed $\left(\mathrm{X}_{1}\right)$ & 100.0 & 15.8 & 100.0 & 44.1 & 100.0 & 3.0 & 100.0 & 5.8 & 100.0 \\
\hline \multicolumn{2}{|c|}{ Analysis Feed $\left(\mathrm{X}_{2}\right)$} & 14.6 & & 44.8 & & 3.2 & & 5.4 & \\
\hline \multicolumn{2}{|c|}{ Standard Deviation (SD) } & 0.8 & & 0.5 & & 0.1 & & 0.3 & \\
\hline
\end{tabular}

Table 6. Testwork results of acid leaching using $\mathrm{HCl}$ for the slimes.

\begin{tabular}{ccccccc}
\hline \multirow{2}{*}{$\begin{array}{c}\text { Leaching time, } \\
\text { min }\end{array}$} & \multicolumn{7}{c}{ Extraction rate \% } & $\mathrm{TiO}_{2}$ & $\mathrm{SiO}_{2}$ & $\mathrm{P}_{2} \mathrm{O}_{5}$ \\
\cline { 2 - 7 } & $\mathrm{La}$ & $\mathrm{Ce}$ & $\mathrm{Y}$ & 17.6 & 3.3 & 96.5 \\
60 & 81.8 & 73.0 & 19.9 & 17.1 & 0.0 & 93.7 \\
120 & 89.3 & 77.8 & 19.9 & 18.0 & 0.0 & 91.4 \\
180 & 89.3 & 79.8 & 25.2 & 18.0 & \\
\hline
\end{tabular}

\subsubsection{Process Mineralogy}

Modal mineralogy of the flotation REE-Ti concentrate (Flo REE-Ti Conc) was determined by MLA analysis. The modal mineralogies of Flo REE-Ti Conc and the Feed are compared in Table 7. It is seen that target minerals allanite, apatite and titanite were significantly enriched, that is, allanite was enriched from $1.87 \%$ to $3.85 \%$, apatite from $1.24 \%$ to $5.62 \%$, and titanite from to $15.43 \%$ to $78.57 \%$. Major silicate minerals biotite, plagioclase and K_felspar but garnet was removed in the flotation concentrate. Meanwhile, the contents of Fe-oxides are low in the Flo REE-Ti Conc. Garnet was concentrated into Flo REE-Ti Conc which could be due to its similarity to allanite, apatite and titanite on crystal properties and floatability [10].

The contents of biotite, allanite and titanite in the gravity (Gra), HGMS and composite (COMP) REE-Ti concentrates and the biotite concentrate were calculated and the results are shown in Table 8.

Biotite was concentrated from $31.6 \%$ to $66.3 \%$ in the biotite concentrate. The contents of biotite in the REE-Ti concentrates were reasonably low, that is, $1.52 \%, 0.91 \%$ and $2.0 \%$ in the COMP, Gra and HGMS REE-Ti Concs, respectively.

Allanite was concentrated in the REE-Ti Concs, that is, from $1.9 \%$ in the feed to $5.48 \%$ in COMP REE-Ti Conc, 5.9\% in Gra REE-Ti Conc and 5.2\% in HGMS REE-Ti Conc. Meanwhile, titanite was significantly enriched in the REE-Ti Concs, that is, from $15.4 \%$ in the feed to $71.19 \%$ in COMP REE-Ti Conc, $66.1 \%$ in Gra REE-Ti Conc and 75.2\% in HGMS REE-Ti Conc. The contents of allanite and titanite in the biotite concentrate are comparably low at $1.2 \%$ and $10.9 \%$.

Modal mineralogy of the acid leaching residue of the slimes by MLA is shown in Table 9. The content of REE mineral allanite is dropped from $1.87 \%$ in feed to $0.06 \%$ in leach residue or it was almost dissolved into the solution, but titanite is still remained in the solid at a high content of $17.8 \%$. Most remained minerals $(>99 \%)$ in the residue are silicates including plagioclase $49.5 \%$, titanite $17.8 \%$, quartz $11.8 \%$, K_felspar $10.9 \%$, biotite $7.1 \%$ and garnet $1.9 \%$.

\subsubsection{REE-Ti Separation}

The analyses of process mineralogy (Table 8) present that in bulk REE-Ti concentrates allanite and titanite consist of $70 \%$ to $80 \%$. The further investigations in the continuation of this project will focus on the separation of 
allanite and titanite in the bulk REE-Ti concentrates.

According to the mineralogical studies of leaching residue of the slimes (Table 9) acid leaching with $\mathrm{HCl}$ is proved an effective approach to separate allanite and titanite by dissolving allanite into the solution and remaining titanite in the residue. Due to their similar floatability flotation would be challengeable to separate allanite and titanite. But testwork will be carried on to study the possibility such as by using selective collectors (cationic or anionic) and adjusting $\mathrm{pH}$ values etc.

\section{Conclusions}

Mineralogy and beneficiation of the Lamujärvi syenites were studied. In the sample, seven rare earth elements including La, Ce, Pr, Nd, Sm, Gd and Y were found with significant contents over $100 \mathrm{ppm}$ and the total REE (TREE) is $4729 \mathrm{ppm}$. Meanwhile, the sample contains a high content of $\mathrm{TiO}_{2}$.

A total of 18 minerals were identified by MLA analysis in which $89.5 \%$ silicates, $8.6 \%$ Fe-oxides, $1.24 \%$ phosphates and $0.48 \%$ carbonates are contained. Allanite with content of $1.9 \%$ is the major REE-containing mineral and has a coarse grain size. Parisite was identified as another REE-containing mineral but at very low concentration and fine grain size. In addition, the sample has high contents of titanite (15.4\%), biotite (31.6\%) and magnetite (8.2\%). Because allanite and titanite have similar physical (gravitational and magnetic) and surface properties, they could be recovered as co-products by gravity and magnetic separations and flotation. Biotite and magnetite could be recovered as by-products by cationic flotation and low intensity magnetic separation methods, respectively.

Beneficiation flowsheet was developed containing sequent grinding, desliming, WLIMS, shaking tabling, flotation and HGMS. The composite REE-Ti concentrate with the grade of REE (La, Ce, Y) 15235 ppm (TREE $23000 \mathrm{ppm}$ ) at the recovery of $57.2 \%$ and the grade of $\mathrm{TiO}_{2} 25.5 \%$ at the recovery of $54.0 \%$ was obtained. In addition, as the by-products, the magnetic concentrate with the grade of $\mathrm{FeO} 86.6 \%$ at the recovery of $45.6 \%$ and the biotite concentrate with the grade of $\mathrm{MgO} 6.6 \%$ at the recovery of $51.0 \%$ were achieved. The REE in the slimes fraction were efficiently leached (recoveries of $89.3 \% \mathrm{La}$ and $79.8 \% \mathrm{Ce}$ ) with hydrochloric acid ( $\mathrm{HCl}$ ) at concentration $6 \mathrm{~mol} / \mathrm{l}$ and temperature $60^{\circ} \mathrm{C}$.

Table 7. Modal mineralogy comparison of feed and REE-Ti flotation concentrate.

\begin{tabular}{|c|c|c|c|c|c|}
\hline \multirow{2}{*}{ Mineral } & \multicolumn{2}{|c|}{ Wt $\%$} & \multirow{2}{*}{ Mineral } & \multicolumn{2}{|c|}{ Wt\% } \\
\hline & Feed & Flo REE-Ti Conc & & Feed & Flo REE-Ti Conc \\
\hline Quartz & 0.84 & 0.29 & Titanite & 15.43 & 78.57 \\
\hline Plagioclase & 30.87 & 1.31 & Calcite & 0.48 & 0.00 \\
\hline K_feldspar & 6.04 & 0.65 & Apatite & 1.24 & 5.62 \\
\hline Biotite & 31.63 & 2.23 & Magnetite & 8.21 & 0.08 \\
\hline Garnet & 2.41 & 6.15 & Ilmenite & 0.12 & 0.21 \\
\hline Allanite & 1.87 & 3.85 & Goethite & 0.29 & 0.01 \\
\hline Zircon & 0.37 & 0.41 & & & \\
\hline Parisite & 0.01 & 0.02 & Total & 99.81 & 99.41 \\
\hline
\end{tabular}

Table 8. Contents of biotite allanite and titanite in REE-Ti concentrates and biotite concentrate.

\begin{tabular}{|c|c|c|c|c|c|}
\hline \multirow[b]{2}{*}{ Mineral } & \multicolumn{5}{|c|}{$\mathrm{Wt} \%$} \\
\hline & Feed & $\begin{array}{l}\text { COMP REE-Ti } \\
\text { Conc }\end{array}$ & Gra REE-Ti Conc & $\begin{array}{l}\text { HGMS REE-Ti } \\
\text { Conc }\end{array}$ & Biotite Conc \\
\hline Biotite & 31.63 & 1.52 & 0.91 & 2.03 & 66.30 \\
\hline Allanite & 1.87 & 5.48 & 5.87 & 5.17 & 1.23 \\
\hline Titanite & 15.43 & 71.19 & 66.14 & 75.16 & 10.92 \\
\hline
\end{tabular}


Table 9. Modal mineralogy of the acid leaching residue of the slimes.

\begin{tabular}{|c|c|c|c|c|c|}
\hline \multirow{2}{*}{ Mineral } & \multicolumn{2}{|c|}{ wt $\%$} & \multirow{2}{*}{$\begin{array}{c}\text { Mineral } \\
\text { Feed }\end{array}$} & \multicolumn{2}{|c|}{ wt\% } \\
\hline & Feed & Leach Residue & & Feed & Leach Residue \\
\hline Quartz & 0.84 & 11.82 & Zircon & 0.37 & 0.16 \\
\hline Plagioclase & 30.87 & 49.47 & Allanite & 1.87 & 0.06 \\
\hline K_feldspar & 6.04 & 10.86 & Apatite & 1.24 & 0.01 \\
\hline Biotite & 31.63 & 7.11 & Calcite & 0.48 & 0.01 \\
\hline Garnet & 2.41 & 1.90 & Ilmenite & 0.12 & 0.18 \\
\hline Titanite & 15.43 & 17.77 & Total & 91.30 & 99.30 \\
\hline
\end{tabular}

Studies of process mineralogy present that allanite and titanite are successfully concentrated and that major silicate minerals biotite, plagioclase and $\mathrm{K} \_$felspar are significantly removed by gravity separation, high gradient magnetic separation and flotation processes for REE-Ti. Meanwhile, acid leaching with HCl could be an effective approach to separate allanite and titanite for further treatment of the REE-Ti concentrate.

\section{Acknowledgements}

The authors are grateful to the Ministry for Foreign Affairs of Finland for the financial support.

\section{References}

[1] Goodenough, K.M., et al. (2016) Europe’s Rare Earth Element Resource Potential: An Overview of REE Metallogenetic Provinces and Their Geodynamic Setting. Ore Geology Reviews, 72, 838-856. http://dx.doi.org/10.1016/j.oregeorev.2015.09.019

[2] Sarapää, O. and Sarala, P. (2013) Rare Earth Element and Gold Exploration in Glaciated Terrain-Example from the Mäkärä Area, Northern Finland. Geochemistry: Exploration, Environment, Analysis, 13, 131-143. http://dx.doi.org/10.1144/geochem2012-136

[3] Arzamastsev, A., et al. (2008) The Khibina and Lovozero Alkaline Massifs: Geology and Unique Mineralization. 33 IGC Excursion No. 47, Apatity, 22 July-2 August 2008, 1-58.

[4] Zaitsev, A.N., et al. (2014) Rare-Earth Elements Minerals in Carbonatites of the Kola Alkaline Province (Northern Fennoscandia). 1st European Rare Earth Resources Conference, Milos Island, 4-7 September 2014, 343-347.

[5] Al Ani, T. and Sarapää, O. (2013) Geochemistry and Mineral Phases of REE in Jammi Carbonatite Veins and Fenites, Southern End of the Sokli Complex, NE Finland. Geochemistry: Exploration, Environment, Analysis, 13, 217-224. http://dx.doi.org/10.1144/geochem2011-088

[6] Vartiainen, H. (1980) The Petrography, Mineralogy and Petrochemistry of the Sokli Carbonatite Massif, Northern Finland. Geological Survey of Finland, Bulletin 313, 126.

[7] Sarapää, O., et al. (2013) Rare Earth Exploration Potential in Finland. Journal of Geochemical Exploration, 133, 2541. http://dx.doi.org/10.1016/j.gexplo.2013.05.003

[8] Fandrich, R., et al. (2007) Modern SEM-Based Mineral Liberation Analysis. International Journal of Mineral Processing, 84, 310-320. http://dx.doi.org/10.1016/j.minpro.2006.07.018

[9] Gu, Y. (2003) Automated Scanning Electron Microscope Based Mineral Liberation Analysis An Introduction to JKMRC/FEI Mineral Liberation Analyser. Journal of Minerals \& Materials Characterization \& Engineering, 2, 33-41. http://dx.doi.org/10.4236/jmmce.2003.21003

[10] Zeh, A. (2004) Crystal Size Distribution (CSD) and Textural Evolution of Accessory Apatite, Titanite and Allanite during Four Stages of Metamorphism: An Example from the Moine Supergroup. Scotland. Journal of Petrology, 45, 2101-2132. http://dx.doi.org/10.1093/petrology/egh049 


\section{Submit or recommend next manuscript to SCIRP and we will provide best service for you:}

Accepting pre-submission inquiries through Email, Facebook, LinkedIn, Twitter, etc.

A wide selection of journals (inclusive of 9 subjects, more than 200 journals)

Providing 24-hour high-quality service

User-friendly online submission system

Fair and swift peer-review system

Efficient typesetting and proofreading procedure

Display of the result of downloads and visits, as well as the number of cited articles

Maximum dissemination of your research work

Submit your manuscript at: http://papersubmission.scirp.org/ 